\title{
PROCEEDINGS
}

() THE

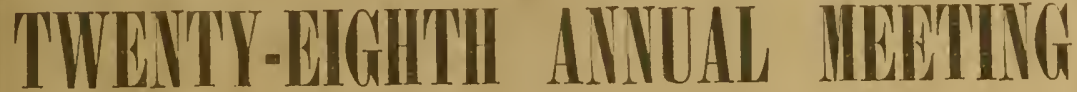

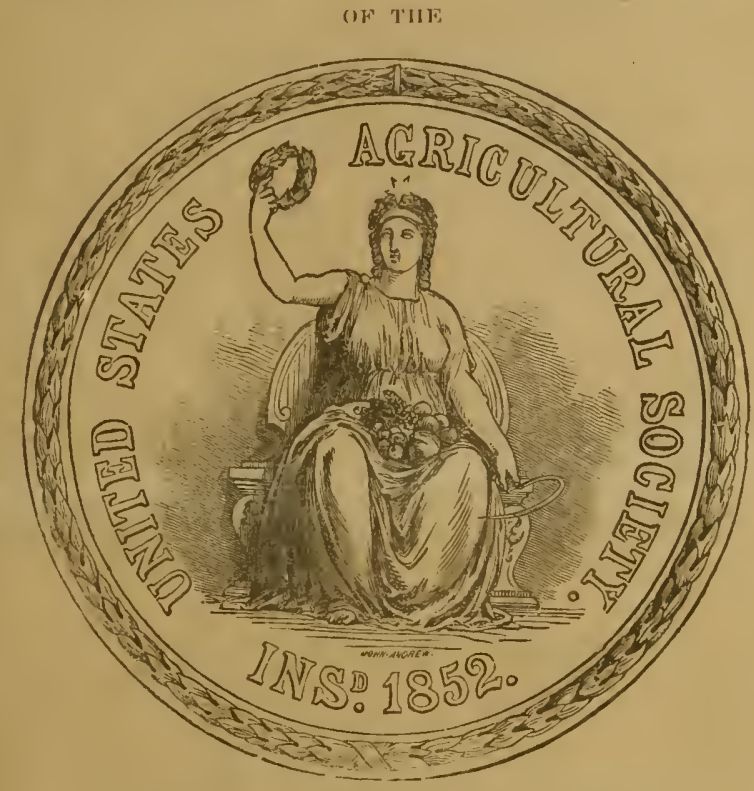

JAIUARY 14, 1880.

WITII

THE CHARTER, LISTS OF THE MEMBERS, $\triangle \mathrm{D}$

AN ADDRESS TO THE MEMBERS.

WASHINGTON, D. C.:

R. O. POLKINHORN, PRINTER.

1880 . 



\title{
PROCEEDINGS
}

\author{
OF THE
}

\section{'JWENTY-EIGHTH ANNUAL MEETING}

of T!H:

\section{UNITED STATES AGRICULTURAL SOCIETY.}

The United States Agrieultural Society held its Twenty-eighth Anumal Meeting at the office of its Secretary, 1:319 F street, Washington, D. C., on the 1tth of January, 1880.

Bex: Perley Poore, Seeretary of the Society, called the meeting to order at 9 o'elock, a. m., anu in the absence of the President, invited Vice President RandoLPh, of Texas, the senior Vice President present, to take the ehair.

The minutes of the Twenty-seventh Annual Meeting were read and approved.

On motion of Mr. LaNe, of Indiana, seeonded by Mr. Hopkiss, of West Virginia, the Society.proceeded to the annual election of its officers, and the Chair appointed Messrs. Lane, Hopkins, and Freneh of New Hampshire, a eommittee to receive, sort and eount the votes.

Mr. Poore, of Massaehusetts, stated that the Hon. Fred. Smyth, who had adhered to the Society in its adversity and its prosperity, deelined a re-election as President.

The eommittee appointed to receive, sort and count the votes for officers of the Society for 1880-'81, reported that the following list had been electerl: 
PRESIDENT, JOHN MERRIMAN, of Maryland.

VICE-PRESIDENTS :

Alabama.... ............... T. E. Tichner.

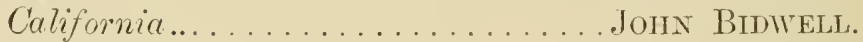

Coloralo.................... Roger TV. Wuodrury.

Connecticut...................'H. Hron.

Dacota....................... . . . . PATTEE.

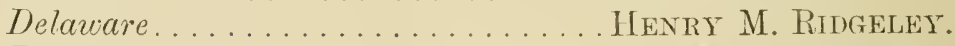

District of Columbia............. W. W. Corcorax.

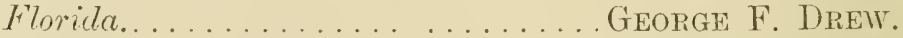

Georgia................... T. W. Avers.

lllinois .................. D. GILLETT.

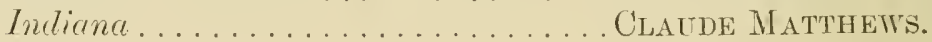

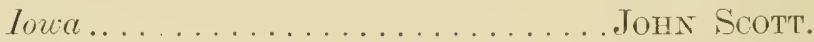

Kansas................... T. C. Henry.

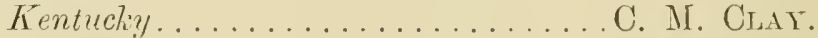

Louisiana. . . . . . . . . . . . . . . J. FLord KING.

Maine ................... R. BARDWELL.

Maryland...................ERA THITHAN.

Massachusetts................. WM. SutTen.

Michigan..................... G. IVELIs.

Minnesota................... IV. Thompson.

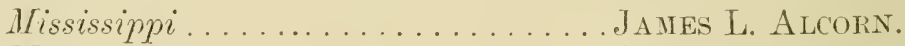

Missouri.................... C. SWAlLow.

Nebrastia .................. D. H. Whenter.

Nevada ................... JoHN P. Jones.

New Hampshire... . . . . . . . . . . . . Moses Humphrex.

Neu Jersey . . . . . . . . . . . . . GEorge H. Cook.

Neu Mexico..........................................

North Carotina ................ L. L. PoLk.

Ohio .................... C. Sterexs.

Oregon ...................... G. ReED.

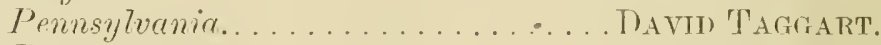

Rhode lsland ............... ELISHA DyER.

South Carolina. . ............... . . W YATT AIkEN.

Tennessee ................... B. KILLEBREW.

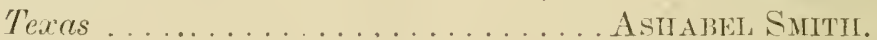

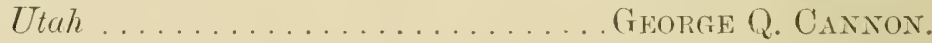

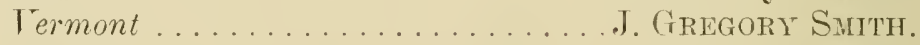

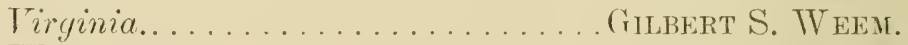

Trastimgton ................. Thovas H. BRliNts.

Wisconsin ................ CHFster HAZFN. 
EXECUTIVE COM MITTEE:

Fred. Surtit, of New IIanpshire, Chairman.

A. S. Towrshent, of Ohio ;

Willay S. King, of Minnesota;

A. L. Kensens, of Pennsylvania;
RoBERT BEVERLY, of Virginia;

N. M. CurTis, of New York;

A. II. FulFord, of Maryland.

Lix Officio Members.

Johr Merryman; of Maryland;

Ben: Perley Poore, of Mass.

SECRETARY,

BEN : PERLEY POORE, of Massachusetts.

(Ofice: 1319 F Street, Washington.)

TREASURER,

WILLTAN M. FRENCH, of New Hampshire.

(Office: 1319 F Street, Washington.)

On motion of Mr. Hopkins, of Pennsylvania, seconded by Mr. Powers, of Ohis, it was-

Litsolced, That the President, Secretary, and Execotive Committee take such measures as they mateem expedient to revive the operations of the United States Agricultural Society, which were interrupted by the civil war in 1861 , and especially to invite the conperation of State, connty, and local organizations for the advancenent of agriculture.

() motion of Mr. Poore, of Massachusetts, seconded by Mr. HiLDhETH, of Tennessee, it was--

Pesolved. manimously, That the congratulations of the United States Igricultural Society le tendered to its houored founder, Marshall P. Wilder, of Massachusetts, with the expression of the gratifieation of those of its members assembled at its twenty-eighth annual meeting, that his valuable life has been spared, while so many of the alder members have been removed from the field of their labors by the grim leaper, Death.

After soine informal conversation as to the best way for resuseitating the active operations of the Society,

On motion of Mr. HAYEs, of California, the meeting was adjourned sine die. 


\title{
THE CHARTER
}

OF THE

\section{UNITED STATES AGRICULTURAL SOCIETY,}

\author{
Granted by Act of Congress in 1860.
}

\begin{abstract}
Be it enacted by the Senate and House of Representatives of the United States of America in Congress assembled, That William W. Corcoran, Benjamin B. French, Benjamin Ogle Tayloe, Ben. Perley Poore, and John A. Smith, their associates and successors, be, and they hereby are, made, declared, and constituted a corporation and body politic within and for the Distriet of Columbia, in law and in fact, to have continuance forever, by the name and style of "The United States A gricultural Society ;" and by such corporate name, style, and title shall be hereafter forever able and capable, in law and equity, to ste and be sued, plead and be inpleaded, answer and be answered unto, defend and be defendied, in any conrt or courts, or other places, and before any judge or judges, justice or justices, or other persons whatsoever, within the District of Columbia, in all and every manner of suits, actions, complaints, pleas, causes, matters, and demands of whatever kind or nature they may be, in as full and effectual a manner as any other person or persons, bodies politic or corporate, may or can do.
\end{abstract}

SEC. 2. And be it further enucted, That all and singular the goods, chattels, and other effects of what kind or nature soever, heretofore given, granted, or devised to the said society, or to any person or persons for the use thereof, or that may have been purchased for or on account of the same, be, and the said goods, elattels, and other eflects are herely vested in and confirmed to said corporation; and the said corporation may take and receive any sum or sums of money, or any gorods, chattels, or other effects of what kind and nature soever, which shall or may hereafter be given, granted, or bequeathed unto them by any person or persons, bodies corporate of politic, eapable of making such gift, grant, or hequest: Provided, That the goods, chattels, and other eflects vested in and confirmed to said corporation, and the moneys, goods, chattels, and other eftects which by this act the satic corporation is atthorized hereafter to receive, shall not in the whole exceed the value of one hundred thousand dollars.

SEC. 3. And be it further tnucted, That the anntial meeting of the United States Agricultural society shall be held in the city of Washington, on the second Wednesday of Jantary in cach and every year, at which meeting there shall be elected, in such manner as the constitution or lyy-laws of the society may provide, a president; such a number of vice-presidents as may be fixed upon by the constitution or by laws; an executive committee, to consist of seven members, in addition to whom the president and secretary shall be ex offieio members, and of which the president shall he chairman; a treasurer and secretary-all of whom shall hold their offices for one year, and mutil their snccessors are elected. The duty of the president shall be to preside over the deliberations of the society, and to liave a general supervision of its affairs. The duty of the treasurer shall be to rereive and keep safely all the moneys of the society, and to disburse the same under the direction and supervision of the executive committee; he shall give bonds for the faithful performance of bis duties, in such penalty as may be fixed, and such surety as may he approved by the president. The duty of the secretary shall be to keep all records of the doings of the society; to conduct the correspondence especially appertaining to his office; to keep the seal and make certificates under the salme; to issue medals, certificates, and diplomas; and to superintend all publications emanating from the society. All these officers, and the executive committee, shall perform such duties and additional duties as may be 
prescribed by the constitution or by-laws of the society, not inconsistent with the provisions of this act. And if sat election shall not be made at the time prescribed herein, it may be held at some subsequent time within the year.

SEc. 4. And be it further enacted, That the said society shall have full power and authority to make, have, and use a common seal, and the same to break, alter, and renew at pleasure; to make, ordain, establish, and exeeute such constitution and by-laws as they may think proper, and the same to alter, amend, or abrogate at pleasure; to fix the salaries or pay of their oflicers, and to fix the sum that shall be paicl for life or annual membership.

Swe. 5. And be it further enueted, That any person may become a life or annual member of said society by paying into the hands of the treasurer such sum as maly be prescribed in the constitution or lyy laws as the fee for life or annual membership. Honorary members may be elected at the will of the society. It shall require the presence of at least fifteen members of the society to constitute it quorum tor the transaction of business, but a less number may adjourn from time to time.

SEc. 6. And be it further enacted, That the secretary of said eorporation shall keep his business oflice in the city of Washington, and he shall make up a complete record of all the doings of the society annually.

SEc. 7. And be it further enreted, That the constitution, by-laws, and regulas tions of said society as.they stand at the time of the passage of this act, shall be und remain in force until altered or abrogated at a regular annual meeting of the corporation; and the officers who were elected at the annual meeting of the society in Jantuary preceding the passage of this act, shall remain in their several offices, and exercise their several cluties, until the annual meeting in the January succeeding the passage of this act, and until their successors are elected.

SEc. 8. And be it further enreted, That Congress may at any time alter, amend, or annul this act.

Approved, April 19, 1860 。

\section{IIONORARY MENBERS}

OF THE

\section{UNITED STATES AGRICULTURAL SOCIETY.}

[Those marked with an asterisk are deceased.]

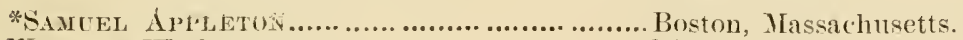

WILlaA W. Corcorax............................. Washington, Dist. of Col.

* Mrllard Frlidore.................................. Buftalo, New York.

* Abrahan Lincolá................................ Springfield, Illinois.

*Thomas H. Perkins .................................... Boston, Massachusetts.

*Jonathan Philitips. ............................... Boston, Massachusetts.

*Fraxklia Pierce......................................... Concord, New Hampshire.

Josiair Quixcy ....................................... Boston, Massachusetts.

*Eduund Ruffin. .................................. Malhourne, Virginia.

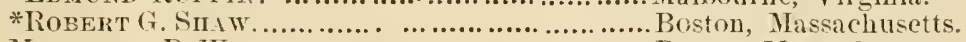

MARshal P. W ILDER ................................ Boston, Massachusetts. 


\section{LIFE MEMBERS}

OF THE

\section{UNITED STATES AGRICULTURAL SOCIETY.}

[Some of the following list are dead, and in the next edition their names, so far as ascertained, will be marked with an asterisk. ]

Abbe, R. MI. Thompsonville, conn. Adams, Janiel, Newhuryport, Mass. d dims, Jonatlian $\mathrm{S}$. Mordenstown, N. J. Altums, TVilliam, Boston, Mliss.

Aflleck, Thomas, Bromhrm, Texas.

Alston, Benjamin, Geoructomn, S. C

Arunory, Thomas, Boston, Mase.

Arny, IV. F. MI., Hyatt, Kinsas.

dreriog, Thoma $=$ (H. Passatic, N.J.

Bailey, Dudley H., Boston, Mass.

Bniley, Whan Carter. West Newhimy, Mass

Balley, Lewis, Fairlax Co., Ya.

Bakej, Abijah R. West Nexiham, MIass.

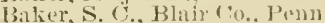

B.lch, Wesley P., Tr., Buston, Mass.

lualiwin, Ilarver, symase. N. Y.

Ballance. Charles. Peoria, IH.

Hallon, II Iturin II. Bostom. IIass.

Bancrolt, Tames. Charbestom. S. C.

Barrett. J. IV., Nit. Lomis, IIo.

Barrows Honay D. Los Angelos Cal.

Berker, Barney S.. Sirracuse. N. Y

Beekman, J. S., Kinderhook, N. Y

Benson. Sammel P.. TYinthro1, Hine.

Berckman, Emile C... Plainfield, N. J.

Brrektan, Louis E.. Plainfield. N.J.

Bercliman. Prosinel. I. Na infield, N.J.

Billings. Hammet, Buston, Mrass.

Billinus, H. MT, ITiohlnud, Wis.

Billings, Toseph H.. West Roxbury, Mass.

Blake, George B.. Bustun, Mass.

Blake, John R.. Bostom, Mas.

Bolmas, A. T. Westchester, Penn.

Bowie, iv. W W W. Goremor's Bridge, Md

Brardforel. A. C.. Stocktum, Cal.

Bradford. S. S.. Culpepper C. H., Va.

Brand, A. H., Texington. ky.

Brewer, Flancis. Sintinzfied Mlass.

Bridres, R. R.. Fulqe(oml, N. C.

Bromks. DeLorinal. Beloit. IT is.

Broolis Tohn. Princeton Mlass.

Brown, J). Tay, Mashington, D. C.

Brown, James N., sipriugtield, 111.

Brown, Lewis B., New Yorli City.

Brown, simon, ( (a)

Brown, Willian Iome. Omaha City, Neb.

Buckelen. Tames, Jameshurw, N. J.

Buckey. Jaeoh II, Frederick, Mli.

Bucliley. J. L. Tr. Bustori, Mass.

Bu!l. E. IV. Coneord. M1 as:.

Bumckle, W. D.. Pliladelphia, I'enn.

Burgess, Fiward I’. Deilham, Mass.

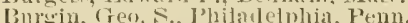

Burroyn, H. R.. (tarysume, N. C.

Burneti, f. 13. syracise. N. $\mathrm{Y}$.

IButman, Greoreno F, Bustun, Miass.

Byineton, A. Homer, Nerwalle. Coms.

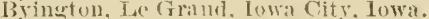

(ilvert, (harles D. Wasingetom, 1). C.

(amnon. John M.. Darenjort. lowa.

carey, F. G., Colibere Hill, Ohio.

Case, Eliphalet l'atriot. Inch.

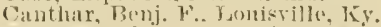

('ilaffer, Calvin, syminglield, Mass.
Chamberlain. Daniel. Boston, Mass.

Champion, Thomas, Vishingtou, D. C.

Chapman, Alfred, Stamnton, Va.

Chase, Albion, Athens, Ga.

Clayp, Henry WV.. Greenfield, Mass.

Chement. Aaron, Philaiblutia, Penn.

Coleman, Thomas II.. Philadelphit, Penn.

Colvin, B., F., Syramse, N. Y.

Comins, Linus B.. Bustom. AI ass.

Conger, A. B. Rocklimd Co., N. Y.

Comklin, E. K., Phila lelphia, ['emn.

Connolly, Thomas C., Washington, D. C.

Converse, James C., Boston, DIass.

Cook, A. P Broukline Mich.

Cook, George Lewis, Warren, R. I.

Cook, Tolm I., Syritise. N. I.

Couke, Josewh I... Providence, R. I

(ooper, S., Buston, Mass.

Copeland. R. Morris. Buston, MIass.

Gopenhagen, Arnold iV., Dorehester, Mass.

Corcoran, IV. IV.. Waxhington, D. C.

Comell, E. Ithica $\mathrm{N}, \mathrm{r}$.

Cornell, isane R., iveston, N.J.

Curing, Henry, Cormus Ciristi. Texas.

Coxe, Richard si. IVashinetom. D. C

('ripuen, J. B.. Cold Titer. IIich.

Crockett, Selden, Bustor, Mass.

Comninghim, C. Jorine. Boston, MIass.

Curtis, Thomas B. Boston, Mass.

Curtiss. D. S., MLainsun, Wis.

Cushman, Henry IV, Bernaristumn, Mass.

Custis, Geo. IV. P., Ärlington, Vat

Gina, J. B. Syracuse, N. Y.

Darlinston, J. I.. West Chester. Penn.

Darid, Isuac, Worcester, MIss.

Ditris, James, Bustum, Ilass.

Davy, James. Niagara Falls, N. Y.

Delino, Charles, Northamptom. Mass

Dolloti, M., New Jork City.

Demny, Reuhen S., Leicester, Mass.

bick, Robert, Gunesturu, IId.

Dodire, dilen, Georatorn. I). C.

Uodge, B.. Trama, Ind.

Dodige, Harvey, Sutton, Miss.

Dodure J. H Buston. Mass.

Dourdits. William, Belrien simings, MIich.

Durfee. Nathan, Fall River. II

Uyer, Elisbil, Providence, R. 1.

Dyer, Hemy A.. Brouklyn. ('omn.

Eistman, Arthur II. MIanchestur, N. H.

Ederton, E. W., Milwaukie. Wis.

Ellis, James Ml.. Sirracuse, N. Y.

Ellism, Thomas.. Newhumb, N. $\mathrm{Y}$.

Emesson. Rafple, Jr., Rocliford, Ill.

Fialls, Divil.

Faile. Edward C., TV. Farms, TVoodside, N. I. Fleteline. Galduel. Cinclinsfurd, Mlass.

Flint. Chardes J., I

Fout, Solomon, Rutland, I't.

Forbes, R. B., Buston, Miass.

Fowler, IV. C Amherst, Miss.

Francis, John lirown, 'rovilanee, $\mathbf{R}, \mathbf{I}$.

Frazee, J. 11. New Brmmivick, N.J.

Frishec, Rinsoll. Maryland, D. (?. 
French, Ir. 13., Washingtom, I), (). Fremes Hass. French, llenry T., Eveter, N. H. French, Jumathan, Roxlotity, Mass. French, William il., Mashington, 1. C. Fuller A c siom ('ity, l)akotah. (riare, tdison, IT est Cambriclue, Mass.

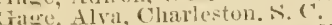
Garber, Jacob B., Columbia, Penn. Garcelon I. Boston. Miass.

Galrison. Ja stratue, N. $Y$. Gay, IIr., symatuse, V. Y. Gibsom Golin. Kóinses iny. Jenn. Giessenhatner, 'T. W., New York, N. Y, Gill WHllium, rolumbus. Olnio.

Gilman. Hon, Clatrles. J.. Brunswiek, Maine. Gillumer, Rubert A. Clien ra, Ill. Gluver. Townsend, Wasington, D. C. Gonll. I. Stanton, Hudsur, N. Y Guuld, James, Lexinertun, Matss Greeley. Horace, New Tork, N. Y. Greenway. Georize, syates, $N$, Y Greenwiy Jolnn, Svracuse, N. Y. Grondyke, A. T., Washington, Ind. Hale, Jostph, Boston, Mass.

Hallis. John W. Brightom, Mass.

Hammond Hon I. H. Beitch Island, S. C

Hanchett, IT. T., Natick, Mass.

Hardenstle. E. L. F., Eiston, Md.

Hatris. IV. A., Buntou, Mass.

Harris, W H Vashrille, Tenu.

Harrison, Charles W. . Andalusia, Penn.

Harrison, N. H.. ILacon. Miss.

Harworl Peter, Barre, Mass.

Hartslorne, Geirure, Rahway, N. J

Jaskins, J. P. Svracuse, N. I

Hasting;, Gr, D ., Tolland, Conn.

Hatch, A. P. Newbern, Ala .

Haren, Frankli!n, Boston, Mass.

Han, $\vec{F}$. MI., Queen Anns, Mal

Healy, Waldo. Dumley, Mass.

Herling. W. H., Sylvinia. Ohio.

Hening, B S Oshkosh, Wis.

Hiekok, $1 \%$. O

Higrinizs, James, Baltimore, MId. Hobis, Ebenezer, Waltham, Mass. Hobbs, Edward i) Lonisrille. Ky Holwes, Georo T Rutland. Vt. Hoiges, Samuel W. . Stongliton, Mass. Hollowiy. Hon, D. I', Richmond, Ind. Holmes, Ezekial, Wiuthrop, Maine Holmes, J. N. Hinstings Centre. N. Y. Holmes. K. G.. Westhoro', Mass. Hophins. Josepli, Wheeling, IV. Va Hosmer, Georye Siracuse, N. Y. Howoh truos Srracuse, $\mathrm{N}$. Ir. Hoyh . T. IV. iIadison. it is

Hubhard. Wiiliam B.. Columbus, Ohio. Hughes, George WT.. West Rirer, Md

Hunnerell, H. H. Boston, Mass

Hunt, Freemin, New York, N. I

Hutt, Wm. II. Sylachse, $N$. Y.

Huntington, Beinamin N.:Rome, N. Y.

Hurhlet, Thomis. Trupue, IId.

Ingersoll, Harry, Philadelplia, Penn.

Jaques, Samuel. Somerville, Mass.

Jay, John. New York, N. Y.

Tenke, William, Alexamdria Co., Ta.

Johnson, B. P. Alhany, N. Y

Jones, Johu, inidaleturn, I lelaware.

Jones, John'T.. Ottawa Creek, Kansas.

Kieith, C. T. Providence. IR. 1

Kelly, .T. R., D.yton. Ohio.

Kelly: William, Rhineback, N. Y

Kemp, Lewis G., Frederick. IId.

Kennedy, Aldred L., Philadelphia, Penn. Femient, John A Irest Northficld. III.

Fimmel, Anthony, New Lomelon. Md. Kine. Tolms A., Tamaica, N. I.

Fing, Willian, Philadeluhin, Penn.

Kuhn, Hartman, Jr., Piilladelphia, Penn.

Kupp. Henry S., Reading, Pa.

Lane, G. W. Indianapolis, Indiana.

Lawrence, Wim. B.. Newport, R. I.

Lawrence, Samuel. Boston, Mass. luwton. William, Now Reclelle, N. Y.

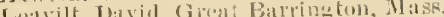

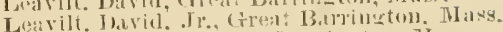

Leavilt, stucleton, Greal Barrineton, Mass.

Jee, tromes Templetom, Mas:

Lee, Hatris, Barre, 11 1s.

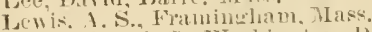

Lewis, Josegh C.. Wasthingtim, 1), C.

I, Wis IV G Farmingiam, IIass.

Lincolu Leri, Worcester, Miss.

Livinuston, Aison, New Yorli, N. Y.

Lloyd, Edward, Jr., Easton, Mil.

Lyon, Henry, Charlestown, Mast.

Tiackall, Louis, Geometown, 1),

Miallory, Rubert, Louistiln ky.

Ilamice, DeFurest. Brushville, N. Y.

Jimn, T. J. St, l'aul, Minn.

Janning. James, syrtense, N. Y.

Mituny, Pells, Freejurt, 1 il.

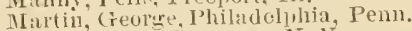

McCarthy. 1)., Syricuse, N. Y.

Tl. Duugall, Syraense, N. Y.

Al-Gowan, Greorge'J.. Philidelihia, Penn.

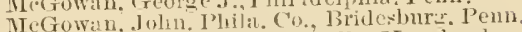

MeHenry, J. Howril. I'ilestille. Maryland.

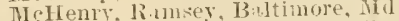

Mellyain, Hugh, Piniladelphia, L'ein.

MeKolden, J.C.. Waslington, D. C.

TLerick, Georoe, Northumberlanu, Penn.

Merryin. John, Cockeysrille, MId.

Miles, James, Girard, Penn.

Miles, J. Y., Hazlewood, S. C.

TIilton iv S Lonisville, Ky.

Tritchell, James L., Albany, N. Y.

IIoore, D. D. T., syracus: N. Y.

Ilorill. J. E., Strafford, Vermont.

Torill J. Stratford, Vermont.

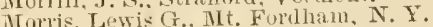

Moseley, Durid, Westlield, Mass.

Iotley. Thomin, Jr., Wust Roxbury, Mass.

Mowry, Sylrester, Tueson, Arizona.

Tunroe, Allen, Syractie, N. Y.

Myers, i. H., San Francisco. Cal.

Nash, I. A.. New York. N. Y.

Newell, Moses, West Yewbury, Mass.

Newhall, Josiah, Lymufield, Mass.

Newhall, Moses, Springfield, Mass.

Newbold, Anthony S., Philadel phia, Penn.

Nichols, Charles, Syracuse, N. Y.

Nightingale, P. Ni. Albany. Georgia.

Nottingham, G.. Syracuse, N. Y.

Olmetead, Henry, East Hilrtford, Conn.

Olcott, Henry S.. New York, N. Y.

Patton. 11. Mi.. Hendersonville. N. C.

Peabody, Georye. London, England.

Penfield, Georwe H, New York. N. Y.

Perham, Jonathan.

Phillip, Jonathan, Boston, Mass.

Pierce, Joshuta, Washington, D. C.

Poore, Ben: Perley. Newberryport, Mass

Poore, walter S., San Francisco, Calitornia.

Prince, wm. R., Flushing, N. Y.

Preston, William T. Frederick, iId.

Quiney, Josiah, Bostun, Wass.

Randili, L. Syractse, N. Y.

Rancloh J H Galveston, Texas

Reese, John L., Baltimore, MId.

Reynolds, John J., TWiek ford, R. I.

Rliodes, B. M. Ballimore, II d.

Rice, John Philadelphia, P'enn.

Rice, Lewis, Boston, Mass.

Ricreley, Chatles, Hamplen. Mrl.

Ridreley. John, Hampden, MId.

Robinson, E. W. Durchester, IIass.

Rockirell, Jolu i Norwicls Con

Rodgers. Henry, Ferrishurg, Termont.

Rogers, Richaril S... Salem, Mass.

Ross, IIarcellus, Pittstield, 111.

Sabin Alra Geumia Termont.

Salesbury, Stephen. Woreester, Mass.

sanderson, Davil. Somerville, N. J.

Sanford, O. S. Curtaiville, Mass.

Sawyer, N. P. Pittsbure, Penn.

Seott, R. W.. Springfield, Ohio.

Sedrewick, E. B.. Straense. K. X. 
Sergeant, Nathan, Washlngton, D. C. Sherman, Duncan.

Sieh, John H., Alviso, California

Silsby, D. H ., Boston, Mass.

Simes, Joseph. Boston, MIass.

Smith, A. L., Syrueuse, N. Y.

Smith, Georre C., Boston, Mass.

Smith, G. P., Nashrille, Temu.

Smith, Samuel P.. Cumberland, IId.

Smyth. Frederick. Manehester, N. H

spence, William A., Montross, Vircinia.

Spooner, William H., Moston, MIass.

stearns. Charles, Springtield, Mass.

Stephens. Paren. Bostom, Mass.

Sterens, E. L.. Clerelant, Ohio.

Stephens, Hon. Iraac J. . Olympia. WV. T.

stewart. WiJiam D.. Syluteuse. N. Y.

sitockwell, S. N. Boston. Mass.

Stone, F. W. Grejph, Camada West.

Stewart, William I., Syraeuse, N. Y .

Stilwell, Niller C., Springfield, Mass.

sutton, William, Salem, Mass.

Talbot, A. G., Danville, Ky.

Tappan, Johr, Boston, IIass

Tayloe, B. O., Washington, D. C.

Tayloe, H. A., Jr. Warsaw, Va.

Taylor, A. J..Syrucuse, N. Y

Taylor, Howell, Somerville, Tenn.

Thayer, Adin, Hoosic Falls, $\mathrm{N}$. $\mathrm{Y}$

Thayer, J. S., New York, N. Y

Thom joson, James. Nantmeket, Mass.

Thompson, James $W^{\prime}$. Wilmington, Del.

Tiluhman, Tench, Oxford, IId.

Todd, Willian B., Washington, D. C.

Trucey, Charles, Norwieh, Comm.

Treadwell, Alfred MI

Twitchell. Genery, Boston, Mass.

Tyler, Philos B., Springfield, Mass.
Underhill, R. T.. Croton l't. Vineyard. N. Y Underwood, Warner L., Bowling Green, Ky. Vinson, Cornelius MI ., Jamaiea Plains, Mass.

Watner, Henry, Rome, N. Y.

Wainwright, Peter. Boston, Mass.

Walley, samuel H., Roxbury, MIass.

Walsh. John Carroll, Hartford Co., Md.

Ware, Josial WY., Berryville. Va .

Waring, Geo. E., Jr.. New York. N. Y.

Walton. Hon. E. P., MIontpelier, It.

Waters, Richard I'. Salem, Ifass.

Watdes, John O., Moneka, Kansas.

Watcon, Winslow MI., Washington. D. C.

Watts, Arthur, Chillieothe, Ohio.

Webster, Joshua, Malden, Mass.

Weleh, A. J.. Syraense, N. Y.

Weld. Amold D. Roxbury Mass.

Wellington, Andrew, East Lexington, Mass.

Wheeler. William F., Grafton, TIass.

Wheelock, J. R., Mendon, Mass.

White. Hamilton, Syraense, N. Y.

White, J. W... Madison, Wiseonsin.

Whiting, Yhavid Y., Santa Fe, New Iexico.

Whiton, Panl, Whitinvile, MLass.

Whitman. E., Baltimore, II

Whitmore Charles O. Boston, Mass.

Whitall, Thomas G., West Roxbury, Mass.

Williams, Aaron D., Roxlury, Mass.

Williams, Willougliby, Nasliville, Teun.

Wilson, W. Duane, Des Moines, Iowa.

Winthrou, Robert C., Boston, II ass.

Wood, Watter A., Hoosie Falls, N. Y.

Woodruff, Jason, Syracuse, N. Y.

Wood ward, Joseph d.. Philadelphia, Penn.

Worthington, James S., Chillicotlic, Ohio.

Wrixht, Eben, Dellham, Mass.

Wyckoff, N., Williamsburg, N. Y. 


\section{ADDRESS}

\section{TO THE LIEE MEMBERS OF THE}

\section{UNITED SI'ATES AGRIGULITURAL SOCIETYY.}

$\ldots+0:-$

The United States Agricultural Society was organized in 1852 , by a National Agricultural Convention, which had met on the 14th of June, 1851, at the Smithsonian Institution, in Washington City, under a call issued by the Massachusetts State Boart of Agrieulture; Pennsylvania State Agricultural Society; Maryland State Agricultural Society; New York State Agricultural Society; Southern Central Agricultural Society ; Ohio State Board of A griculture ; American Institute, New York; Massachusetts Society for the promotion of Agriculture; Indiana State Board of Agriculture ; New IImpshire Agricultural Society ; Vermont Agricultural Society; and the Rhode Island Society for the encouragement of American Industry.

The convention was composed of 153 delegates, representing 23 States and Territories. Among those who were present during its sessions, were the Hon. Millard Fillmore, President of the United States, and the Hon. Daniel Webster, Secretary of State.

The following gentlemen composed the committee who drafted the constitution of the United States Agricultural Society: Messi's. Holcomb, of Delaware; Douglas, of Illinois; J. A. King, of New York; Steele, of New Hampshire ; Thurston, of Rhode Island ; Hubbard, of Connecticut ; Stevens, of Vermont ; Elwyn, of Pennsylvania ; Calvert, of Maryland ; Campbell, of Ohio ; Hancock, of New Jersey ; Callan of the District of Columbia ; G. W. P. Custis, of Virginia; Burgwyn, of North Carolina ; Taylor, of Alabama ; De Bow, of Louisiana ; Spencer, of Indiana ; Mallory, of Kentucky ; Bell, of Tennessee; Weston, of Wisconsin; McLane, of California ; Pickhard, of Maine; Dawson, of Georgia; French, of Massachusetts ; and Seaman of, Michigan.

ANNUAL MEETINGS.

'The Society having been organized, held its first annual meeting at Washington, in February, 1853 , since when they have been regularly continued. Up to 1862 , when the war between the States forced the Society to suspend active operations, these annual meetings constituted, in reality, the central "Board of $\mathrm{Ag}$ riculture," recommended by the Farmer of Mount Vernon. Gentlemen from almost every State in the Union, (many of them delegates from Agricultural Associations, ) annnally assembled to discuss such topics as were presented, calculated to advance the cause of agricultural improvement; interesting and valuable lectures were delivered by practical and scientific furmers; reports were submit- 
ted by committees specially appointed to examine new inventions and theories, and by delegates who were accredited to the agriculturists of other lands; and there was a general interchange of opinion.

\section{NATIONAL EXHIBITIONS}

The Society held its first annual exhibition at Springfield, Massachusetts, on the 17th of October, 1853, and its subsequent exhibitions at Springfield, Ohio ; Boston, Mass.; Philadelphia, Pa, ; Lonisville, Ky.; Richmond, Va.; Chicago, IIl.; and Cincinnati, Olio; besides a National Trial of Reapers and MIowers at Syracuse, New York. Generally self-sustaining; the receipts on these occasions enabled the Society to disburse upwards of two hundred and fifty thousand dollars for premiums and expenses; and they not only increased the efticiency of State and Local Associations, but called together larger assemblages of people than have ever been convened upon other occasions; embracing not ouly our most intelligent yeomanry, but gentlemen of every art and profession from every portion of the wide-spread Union, evincing that the national pulse beat in unison with our own, and that the public voice was responsive to the call.

\section{PUBLICATIONS AND OFFICE.}

When the operations of the Society were suspended it published a Quarterly Journal of Agriculture, and it had at Washington a Secretary's office and readingroom, where the members of the Society and others iuterested in agricultural im. provement could meet as brothers at a common home, and find a collection of objects in which they have a common interest. Many State and County societies contributed their published transactions, premium-lists, the names of their officers, and other information, which were registered, and they received the publications of the Society in returm. A majority of the agricultural aud numerous other publishers contributed their periodicals and newspapers, and thus aided in forming a Free $A$ grieultural Library at the National Metropolis.

\section{FINANCIAL CONDITION.}

The preparations made by the Society for an exhibition at Washington in 1861, which could not beheld, exhausted the small balance in the Society's treasury at that time. The Society has not, however, a dollar of indebtedness. Upwards of two hundred and fifty thousand clollars was received and disbursed by it between 1852 and 1862 , and of this the highest sum ever received by any one of its oflicers in a year was six hundred dollars, which barely defrayed his personal expenses while attending to the business of the Society.

\section{PROPOSITIONS TO BE CONSIDERED.}

With this brief review of what the United States I gricultural Society has accomplished, its officers respectfully ask its life members to consider the following propositions, and to attend the next annual meeting prepared to vote upon them, or any similar questions that may be submitted :

I. Shall the active operations of the United States 1 gricultural Society be resumed; and shall steps be taken to make it, with the co-operation of State and 
Local organizations, worthy of the great interest upon which the pirosperity and happiness of our country is dependent?

II. Shall the officers of the United States Agricultural Society confer with the oflicers of the recently founded American Agricultural Association, with a view to the consolidation of the two organizations?

IIr. Shall the officers of the United States I grieultural Society surrender its charter to the Congress of the United States, which granted it in 1860-deposit its arehives in the Library of Congress-and declare the Society dissolved?

Trusting that you will give these propositions an carnest consideration, and bring them to the attention of all interested parties, so that at the annual meeting, in January next, there may be an unmistakalle declaration of opinion,

We remain yours, very faithfully,

JOHN MERRYMLN, President,

Fred. Simptit, A. S. Townshind, Robert Beveriy, Witidais. King, N. M. Ourtis, A. L. Kennemy, A. M. Furford,

Executive Gommittee.

Ben: Perley Poore, S'ecretary. 


